\title{
Marketing of Banking Service and Its Impact on the Profitability of Ethiopian Private Commercial Banks
}

\author{
Estifanos Yilma (MBA in Finance) \\ Lecturer of Banking and Finance, Dire Dawa University
}

\begin{abstract}
Marketing and advertising is a fundamental concept in the banking industry and profit also the key point which helps them to be surviving in the market. Therefore, this study aims to investigate the marketing of banking service and its impact on the profitability of Ethiopian private commercial banks. The sample of the study included only private commercial banks operating in the country during the study period. To achieve the purposes of the study, and to analyze the data extracted from the annual reports during 2011 to 2017 , the researcher used multiple linear regression method. For this purpose the collected data were analyzed using the STATA14 software. The result showed that positive and significant effect of commission income and number of branches on the profitability of the banks. Whereas there is no significant effect of deposit ratio and advertising expense on the profitability of the bank.
\end{abstract}

Keywords: Marketing mix, profitability, advertising expense, banking service

DOI: $10.7176 / \mathrm{EJBM} / 11-1-03$

\section{Introduction}

Marketing refers to the identification of customers' needs better than competing firms. It also includes predict future needs and develop proper products to the needs of customers. So banks in the competitive environment, constantly changing work needs to have a marketing strategy in the light of a series of best practices to achieve the systematic and practical goal and customer satisfaction (Nokandeh and et al, 2013). With the growing importance of the financial sector, pressures are escalating for more effective marketing management of the financial services. Countries introduced a vast array of new technology hardware, software and telecommunications equipment by spending so many dollars on information technology (Keltner, 1995). The banking industry renders services to customers ranging from acceptance of deposits, opening various categories of accounts - deposit, current and savings account, etc. Afolabi (1988) hypothesizes that banks offer a wide range of financial services to personal and business customers; some of these services which are bank accounts, guarantor ship and investment advisers are needed by an appreciable number of customers, but many other financial services such as import/export services, money transfers, credit cards etc. have to be brought to the attention of potential users, who must be persuaded to use them. Marketing in any organization is to identify the most profitable marketing services now and in the future and assessing the present and future needs of customers. It involves setting business goals; making plans to meet them and managing services in such a way that those plans are achieved (Nwite, 2011).

Heggestad (1977) studies the interaction of market structure, profitability and risk, and argues that banks with monopoly power systematically reduce the risk they take at the expense of greater profitability. Given the importance of bank credit as a factor of production for almost all firms, this effect may plausibly affect market concentration in other sectors of the economy by making the expansion of smaller firms more difficult. According to Chinweoke (2016), Profitability of commercial banks expresses the gains made by banks from their operations, services or products. Profit is the essential prerequisite of a competitive banking institution and cheapest source of fund. Levine (1997) opined also that the outcome of investigations by financial experts on the services banks provide and profitability show a direct relationship between financial development, bank profitability and economic growth in both developed and developing countries. Marcus et al (2017) said that the concept of profit in the banking industry can be seen from the perspective of banks being able to increase revenue and minimize cost to stay afloat through the strategies of products innovation, penetration, positioning, low prices and charges, high sales volume, and ability to meet customers claims or demands when due.

Banking in Ethiopia started in 1905, with the establishment of the Bank of Abyssinia that was owned by the Ethiopian government in partnership with the National Bank of Egypt then under British rule. But a well structure banking system started to evolve starting the 1940s-after the Italian departure. A government owned bank-the State Bank of Ethiopia-was established in 1942, and a number of foreign bank branches and a private bank were operating in competition with the government owned commercial bank until they were nationalized and merged into one government owned mono-bank in 1976. Following the change of government in 1991, and the subsequent measures taken to liberalize and reorient the economy towards a system of economy based on commercial considerations, the financial market was deregulated. A proclamation number 84/94 was issued out to effect the deregulation and liberalization of the financial sector, and a number of private banks and insurance companies were established following the proclamation. In the year 2016/17, there were 16 private banks 
operating along with two public banks, namely the Commercial Bank of Ethiopia and the Development Bank of Ethiopia.

\section{Statement of Problem}

Many services offered by banks are also offered by 'rival' organizations. Building societies have developed customer accounts which are similar in many ways to a bank account. Thrift and cooperative societies provide lending services to their numerous members and indirectly to the society at large. Solicitors act as executors, and trustees and accountants give advice and so on. Banks not only compete with each other but also have to contend with challenges from other types of organization in the market (Soyinbo, 1988). To do this, commercial banks that operating in Ethiopia invest lots of money for promotional activities. Moreover they have budget for product development and marketing research. Some studies have been conducted in related the effect of marketing of bank services on their profitability. For instance; Chinweoke and et al (2016); Micheal Ojo (2012); and AlNimer and et al (2015) are some of researchers who studied the relationship between marketing and profitability. They emphasized on either deposits or advertising and promotion expenses as the independent variables. And they take earnings before interest and tax as the dependent variable. But in this study the researcher used other more variables as the independent variables. Furthermore, this study has used net income as the dependent variable. In addition to the above gap the area by itself is not over emphasized in Ethiopian commercial banks. Accordingly the researcher formulates the following research questions.

1. What is the impact of advertising expenses on banks' profitability?

2. What is the relationship between product type of the banks and their profitability?

3. How banks' profitability affected by the number of their branches?

4. Does the service income of banks affect their profitability?

\section{Objective of the study}

The main aim of this study is to investigate the marketing of banking service and its impact on the profitability of the commercial banks.

In addition to the above general objectives the study has the following specific objectives.

$\checkmark$ To investigate the impact of advertising and marketing expenses on the profitability of the banks.

$\checkmark \quad$ To study the relationship between product type of banks and their profitability.

$\checkmark$ To examine the impact of branch size on banks profitability.

Significance of the study

$\checkmark$ To evaluate the effect of service income of banks on their profitability.

This study has significance for the managers of commercial banks by delivering information about the scientific relationship between marketing and profitability of the banks. The study acts as a source of reference material for future researchers on other related topics; it would also help other academicians who undertake the same topic in their studies.

\section{Literature Review}

\subsection{Theoretical Literatures}

Banking reforms involve several elements that are unique to each country based on historical, economic and institutional imperatives. For example, in the reforms in the banking sector proceeded against the backdrop of banking crisis due to highly undercapitalization of state owned banks; weakness in the regulatory and supervisory framework; weak management practices; and the tolerance of deficiencies in the corporate governance behavior of banks (Gyargy Szapáry, 2001). In the Yugoslav economy, banking industry restructuring was motivated by the need to establish a healthy banking sector that will carry out its financial intermediation role at a minimal cost; effectively provide services consistent with world standards and which will involve foreign financial institutions; and banks privatization as the ultimate goal. The central focus was to shore up the capital base of banks consolidated through mergers and take overs of local banks and selection of strategic investors for additional capitalization. Specifically, foreign banks permeated the industry exclusively by providing additional capitalization through investment in the existing infrastructure, particularly new banking products and operating technologies and buying shares of the existing banks. Also, the banking sector reforms and consolidation in Japan involved the reform of the regulatory and supervisory framework, the safety net arrangements, as well as mechanisms to speed up attempts at resolution of banks' non-performing loans. From the above, it is obvious that the fundamental objective of banks consolidation is the repositioning of the banking industry to attain an effective and efficient status that will promote economic development. Consequently, consolidation has increased the level of competition in the industry and this in turn has increased the marketing activities in the Nigerian banking industry as well as other nations of the world.

\subsubsection{Marketing Strategy Models}

Various models and have been developed empirically to analyze the impact of marketing strategies on corporate performance. Some of these empirical studies are reviewed below: 


\subsubsection{The Resource Based View (RBV)}

This model recognizes the importance of a firm's internal organizational resources as determinants of the firm's strategy and performance (Grant 1991; Wernerfelt 1984,). Grant (1991) defines the term internal organizational resources as all assets, capabilities, organizational processes, firm attributes, information, knowledge, that are controlled by a firm and that enable it to envision and implement strategies to improve its efficiency and effectiveness. Although the RBV recognizes that a firm's physical resources are important determinants of performance, it places primary emphasis on the intangible skills and organizational resources of the firm (Collis, 1991). Some intangibles resources of the firm are the market-assets such as customer satisfaction and brand equity.

\subsubsection{The Dynamic Capabilities Model}

The Dynamic Capabilities view strengthens the RBV, it emphasis on how combinations of resources and competences (Teece et al., 1997) can be developed, deployed and protected. The factors that determine the essence of a firm's dynamic capabilities are the organizational processes where capabilities are embedded, the positions the firms have gained (e.g. assets endowment) and the evolutionary paths adopted and inherited. Based on this perspective, the marketing factors that determine the competitive advantage are marketing efficiency resulting from the marketing organizational process and the endowments of market assets that has generated such as customer satisfaction and brand equity, i.e. marketing positions.

In the context of global competition, RBV and Dynamic capabilities theory suggest that historical evolution of a firm (accumulation of different physical assets and acquisition of different intangible organizational assets through tacit learning) constrains its strategic choice and so will affect market outcomes (Collis, 1991). According to Douglas and Craig (1989), the development of a Marketing Strategy is carried out during the stage of global rationalization. It means that the firm has had to take the step of initial foreign market entry and expansion of national markets during its process of internationalization. Consequently, in the two previous stages, the firm learned and accumulated not only different physical assets but also different intangible organizational assets; likewise, it faced and took risks in different and complex market contexts. This process of learning affected its performance.

\subsubsection{Marketing Impact Model}

The need for measuring marketing impact is intensified as firms feel increasing pressure to justify their marketing expenditures (Gruca and Rego 2005; Rust et al., 2004; Srivastava et al., 2001). Accordingly, marketing practitioners and scholars are under increased pressure to be more accountable for showing how marketing activities link to shareholder value. It is important to know that marketing actions, such as packaging, brand name, density of the distribution channel, advertising, permanent exhibitions, sponsoring, press bulletins, among others (Van Waterschoot and Van den Bulte, 1992) can help build long-term assets or positions as brand equity and customer satisfaction (Srivastava et al., 1998). These assets can be leveraged to deliver short-term profitability and shareholder value.

\subsubsection{Marketing Efficiency Model/ Data Envelopment Analysis (DEA)}

The other way by which research in Marketing has faced Marketing performance is related to efficiency. Charnes, Cooper and Rhodes (1978) define the efficiency as the comparison among firms of the ratio of outcomes over the inputs required to achieve them. On the other hand, Sheth et al. (2002) define marketing efficiency as the ratio of marketing output over input. Sheth and Sisodia (1995) in referring to their definition of marketing productivity, include two of the dimensions, efficiency as well as effectiveness, i.e. getting loyal customers at low marketing costs. On the other hand, Rust et al. (2004) use the term marketing productivity to refer to how marketing activities are linked to short-term and long-term profits. In reference to literature review,

Charnes et al. (1985) first suggested applying DEA to gain insights into efficiency of marketing efforts. Since then, there have been some marketing studies that used the DEA as a methodology. Kamakura et al. (2002) used DEA to measure welfare loss and market efficiency. Mahajan (1999) studied a DEA model for assessing the relative efficiency of sales units that simultaneously incorporates multiple sales outcomes, controllable and uncontrollable resources, and environmental factors.

\subsection{Empirical Literature}

Oneill et al. (2008) examined marketing expenditures for various hotel tiers, using the Smith Travel Research chain scale categorizations. The researcher found that marketing expenditures have differential effects according to the particular type of marketing expenditure. On the other hand Hardesty and Leff (2010) conducted detailed case studies of three organic farming operations of different sizes and compared their marketing costs and profitability in alternative marketing channels. The researchers classified marketing-related activities into three categories: packing and storage, transportation, and selling and administration. The researchers determined that there are significant variations in marketing costs across marketing channels. For each of three case study farms, marketing costs per dollar of revenue were lowest in the wholesale channel and highest in the farmers' market channel. Significant labor costs for the selling activity and transportation expenses offset the higher prices and 
minimal packaging costs associated with farmers' markets. Profitability can also be significantly affected by marketing factors such as packing and grading standards and product that is used for sampling and consumer premiums.

While Morgan et al. (2009) investigated how market sensing, brand management, and customer relationship management (CRM) capabilities determine firms' revenue growth and margin growth (the two components of profit growth). The study reveals that marketing capabilities have direct and complementary effects on both revenue and margin growth rates, and also found that brand management and CRM capabilities have opposing effects on revenue and margin growth rates, such that a failure to examine these two underlying components would mask the relationships between these marketing capabilities and ultimate profit growth rates. On the other hand Morgan et al. (2009) examine both the possession of a market orientation and the marketing capabilities through which resources are deployed into the marketplace as drivers of firm performance. The researcher's findings indicate that market orientation and marketing capabilities are complementary assets that contribute to superior firm performance. They also find that market orientation has a direct effect on firms' return on assets (ROA), and that marketing capabilities directly impact both ROA and perceived firm performance.

As to Krasnikov and Jayachandran (2008), they examined the effect of marketing capability on firm performance on other capabilities, such as research and development and operations. The researchers found that marketing capability in general, has a stronger impact on firm performance than research-and-development and operations capabilities. Rodriguez and Berrio (2011) studied the relationship between Market Orientation (MO) concept and Financial Performance (FP) in Bogota-based MSMEs. They found that there is no statistically significant impact between Market Orientation construct (intelligence generation; intelligence dissemination; response planning; and response implementation) and Financial Performance (Net Sales, Operating Profit, and their ratio to assets).

Dennis and Taisier (2011) investigated 10 Middle Eastern and North African countries between 2000 and 2008 and made a comparison between accounting profitability measures and economic determinants. The former represents return on assets and return on equity, whereas the latter are related to the efficiency of cost and profit. They found that the size of the bank has a positive effect on its profitability accounting measures. There was a high profitability in those MENA banks studied and little negative correlation between the cost and profit efficiency, despite being smaller. The larger the bank is, the greater the increase in efficiency of cost and profit. Furthermore, cost efficiency was found to have a negative effect on profitability.

Pualinus (2005) examined how the marketing activities of the banks have impacted on their performance over the years and the factors that shape the marketing strategy of the banks. The result showed that there is a significant positive relationship between marketing budget of the banks and their profitability. Akeem (2014) studied on the effect of strategic marketing of financial services on organization performance. The study reveals that there is a significant positive relationship between the financial marketing services and profitability of First Bank of Nigeria Plc.

\section{Methodology}

\subsection{Research design}

The study is a descriptive type of research where characteristics of objects, people, groups, organizations, or environments are described as they are existed. Since data are collected from the financial report of banks, quantitative research approach was employed.

\subsection{Source and methods of data collection}

All private commercial banks are taken as the subject of the study. Financial statements of the banks were used as the source of data. Thus, annual reports of the commercial banks which were published between the years 2011 to 2017 used as the source of data.

\subsection{Sampling design}

All private commercial banks which are operating in Ethiopia were considered as the population of the study. These are; Awash International Bank, Dashen Bank, Wegagen Bank, United Bank, Bank of Abyssinia, Nib International Bank, Cooperative Bank of Oromia, Lion International Bank, Zemen Bank, Oromia International Bank, Bunna International Bank, Berhan Bank, Abay Bank, Addis International Bank, Debub Global Bank and Enat Bank

\subsection{Method of data analysis}

To achieve the objective of the study both descriptive and inferential statistics were used. Hence, panel data of 16 private commercial banks for seven (2011-2017) years were used. Accordingly, the researcher formulated the following OLS model.

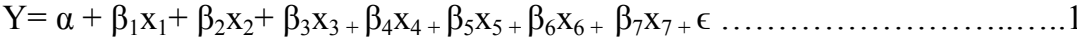


$\mathrm{NI}=\mathrm{f}(\mathrm{DR}, \mathrm{LA}, \mathrm{Adv}, \mathrm{INTER}, \mathrm{COMMS}, \mathrm{BRAN})$ .2

So replacing equation 1 by 2 , we can get the following model;

$\mathrm{NI}=\alpha+\beta_{1} \mathrm{DR}+\beta_{2} \mathrm{LA}+\beta_{3} \mathrm{Adv}_{+} \beta_{4}$ INTER ${ }_{+} \beta_{5+} \beta_{6} \mathrm{COMMS}+\beta_{7} \mathrm{BRAN}+\epsilon$

Where, $\mathrm{NI}$ is Net income

Adv. is advertisement and publicity expense

DR is deposit ratio measure by total deposit to total asset

LR is loan and advances ratio measure by total loan to total asset

INTER is interest income

CMMS is income from commissions and service charges

BRAN is number of branches by the bank

\section{Data Presentation and Discussion}

The data which was collected from financial statements of each private bank were analyzed using descriptive and inferential analysis.

\subsection{Descriptive Analysis}

In this section the researcher tried to show the average advertising expense and average ROE of each banks. Moreover, trend of net income, commission income and advertising expense for the period of 2011 to 2017 were displayed.

\section{Advertize}

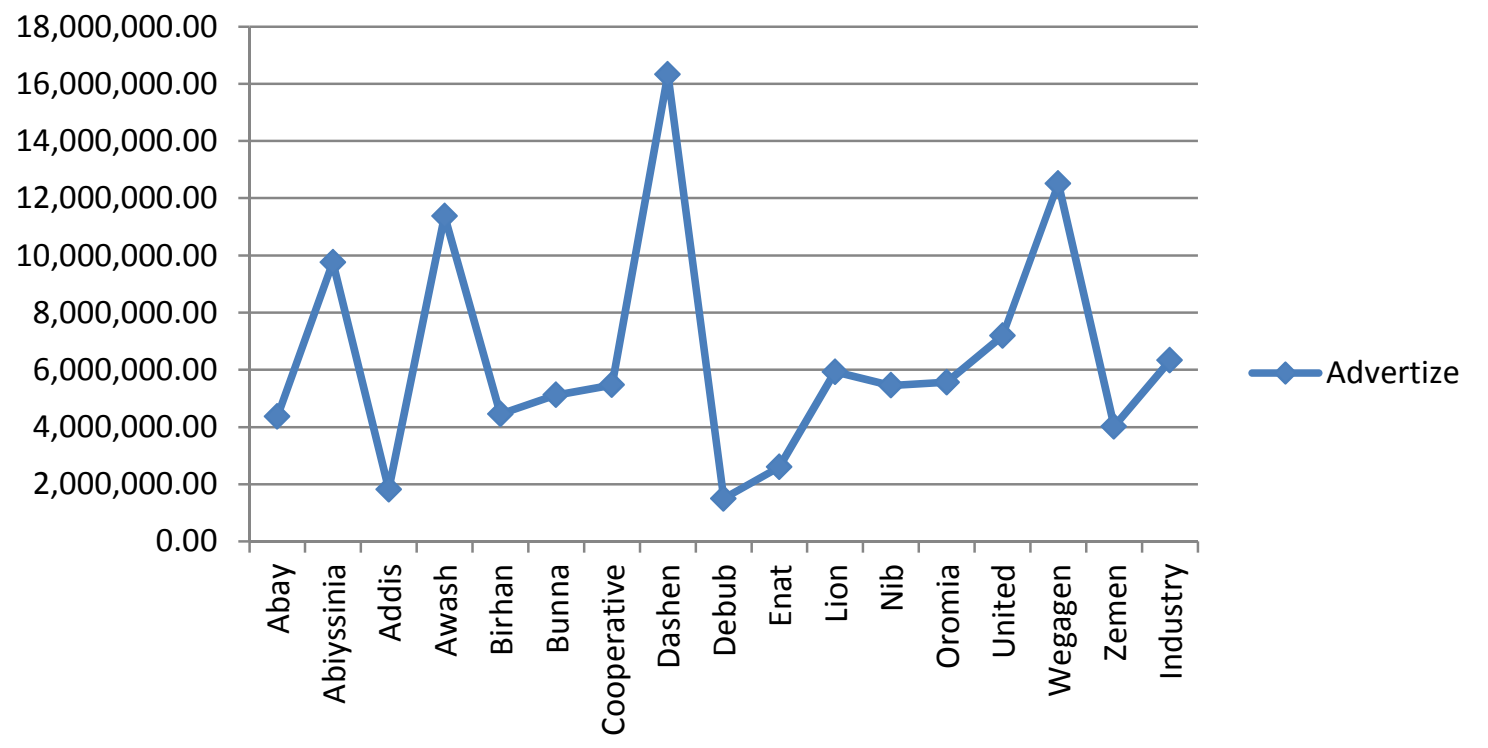

Fig. 1: Average advertisement expenses incurred by banks for the study period

The above chart shows the average advertising expenses of each bank and the average advertising expense of the industry for the study period. It is clearly that Dashen bank has incurred the seven years average advertising expense. Wegagen bank is the second bank which pays high costs for advertising of the bank. Debub Global bank and Addis International bank have spent very low budgets for advertising expense which is very far below the industry average. 


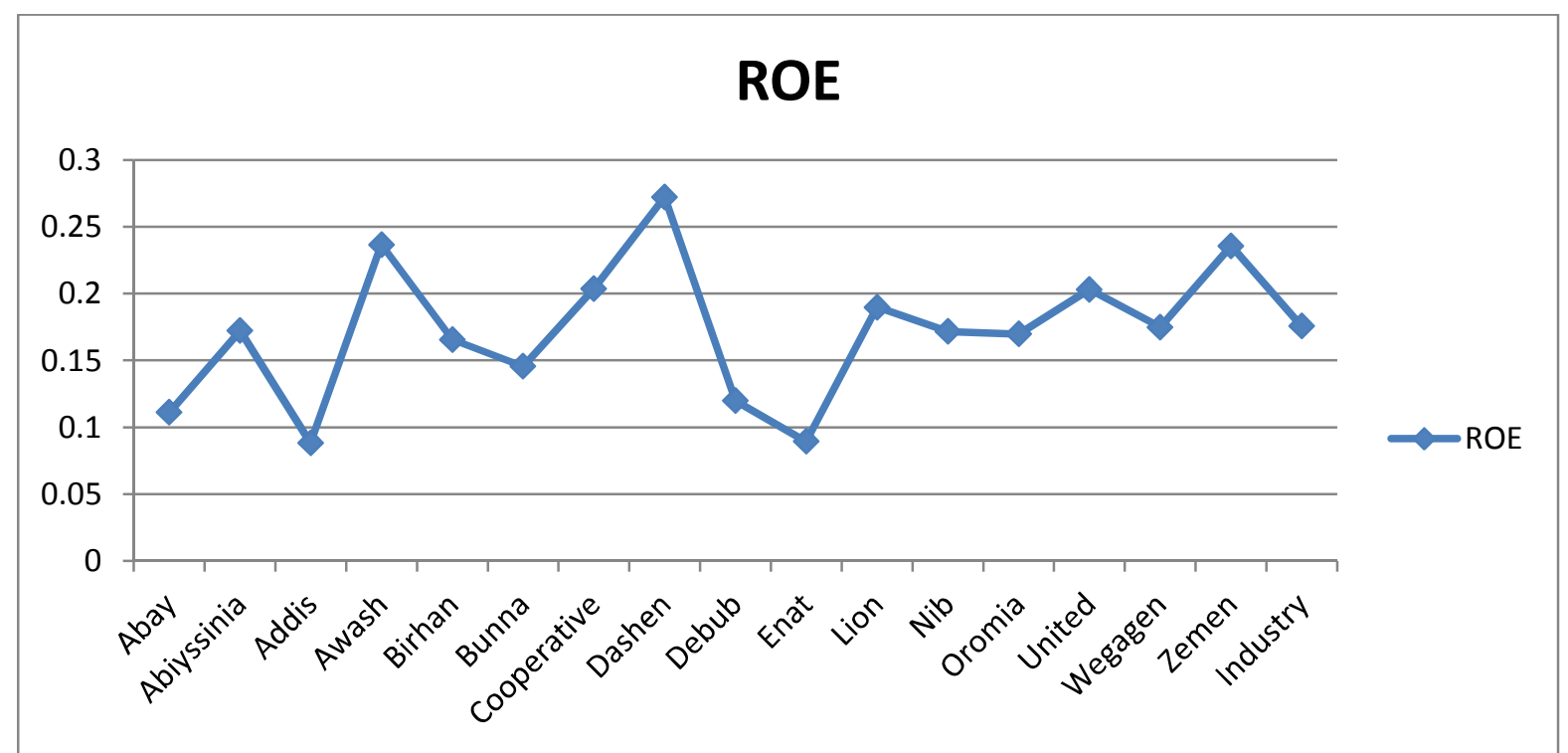

Fig.2: average ROE of banks for the study period

Dashen bank has the highest ROE with the score of 27.2\% followed by Awash bank and Zemen bank with a value of $23.7 \%$ and $23.6 \%$ of return to their shareholders, respectively. Only six banks scored high ROE as compared to the industry average ROE which is $17.6 \%$. Surprisingly, the ROE of Wegagen bank is less than six banks and even from the industry average. But, the bank was incurred high costs for advertising expenses which is ranked it at the second place next to Dashen bank. Zemen bank was incurred very low cost for advertising but has high ROE.

The next chart shows the trend of average net income, commission income and advertising expense of banks for the period of 2011 to 2017. Here, each items are expressed by taking the summation of each banks for the given period of time.

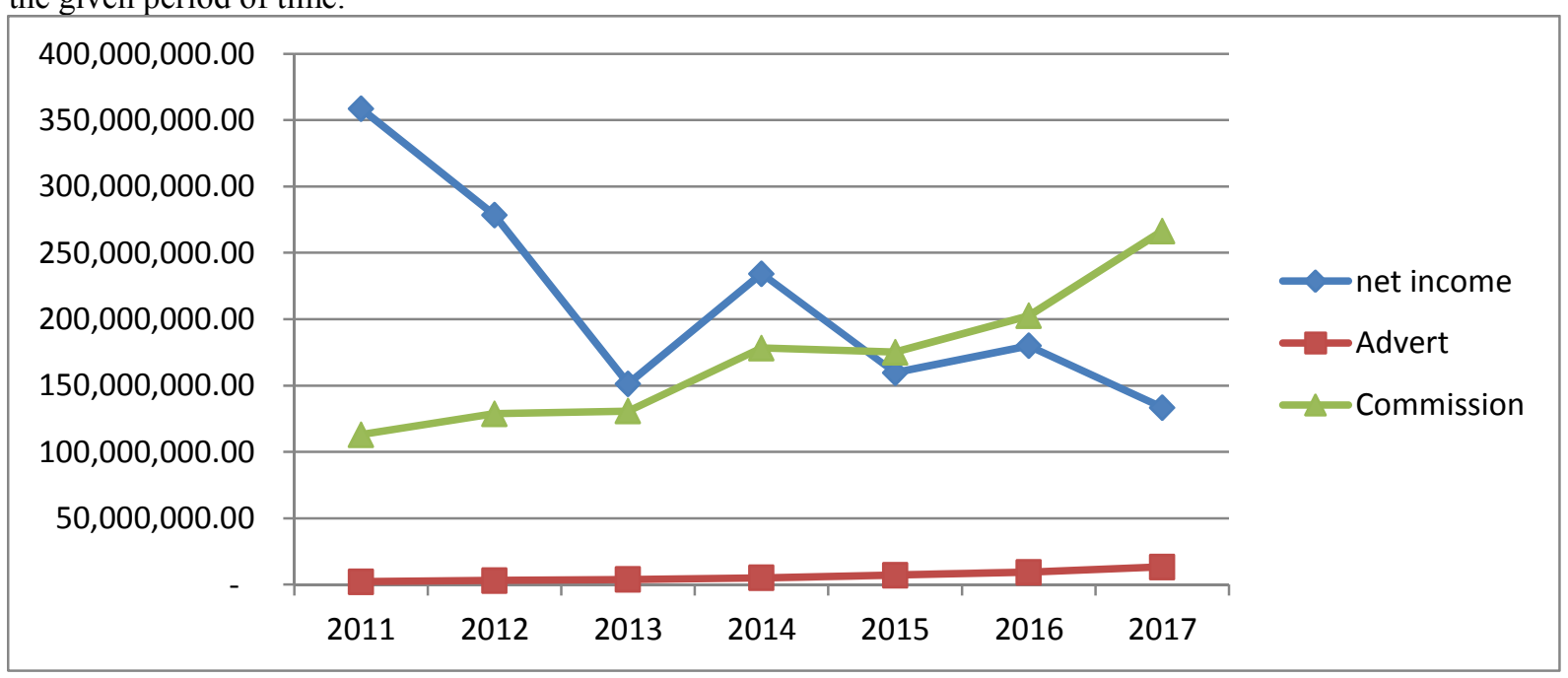

Fig.3: Trend of NI, Commission Income and Advertising expense for the period of 2011 to 2017

The above charts depicts that the average trend of three elements of profit and loss statement of the banks. The green line represents the average commission and service income of all private commercial banks. As it shown in the chart the line starts from the bottom left edge and goes to the upper right edge of the chart. In 2017 fiscal year the amount of commission income increases at increasing rate. This is because banks might be diversified their service by developing variety products which may support them to earn a lot non-interest income. Similarly, the average advertising expense of private commercial banks is increases at lower rate. This indicates that the banks are getting more non-interest income by spending few budgets for promotional activities. In the other words there is high elasticity in non-interest income. Conversely, the line for average net income of banks is decreases from 2011 to 2017. This implied that banks had enormous expenditure for administrative and selling expenses. According to the annual report of each bank they spend more budgets for purchasing of modern technology, particularly for banking software, and they may incurs costs for staff development in order to enhance efficiency and improvement of their service. Furthermore, currently due to high competition and the 
inflation level of the country the employee's salary level become increases from time to time. Besides, Crossed as cited in Pualinus (2005) indicated that the banking industry has been characterized by the development of new products, use of new information technology and increasing complexity in customer's expectation. Competition has become very strong and survival is increasingly becoming difficulty.

\subsection{Inferential Analysis}

In addition to the descriptive statistical analysis discussed above, in this study an econometric model (OLS) was also used to regress the dependent variable (Net Income) in relation to the specified explanatory variables (Deposit ratio, Advertisement expense, Commission income, and number of branches).

Some of variables are excluded from the regression analysis since it was found multi-collinearity problem. Accordingly, so as to treat the multi-collinearity problem two variables viz. loan and interest income were dropped out from the model.

VIF shows how the variance of an estimator is inflated by the presence of multi-collinearity. Therefore the next table indicated that the model do not has multicolinearity problem.

\begin{tabular}{|l|ll|}
\hline Variable & VIF & 1/VIF \\
\hline Adv & 3.88 & 0.257647 \\
BRA & 3.66 & 0.273273 \\
COMM & 1.99 & 0.502285 \\
Depositratio & 1.12 & 0.894119 \\
\hline Mean VIF & 2.66 & \\
\hline
\end{tabular}

Thus, as it is presented, the vif result of all variables found below ten (10). It indicates that there is no multicolinearity problem. Besides all other classical model assumptions are tested.

\section{Multiple Regression result}

Before run the regression, the researcher check about the random or fixed effect is appropriate for the model. To choose fixed or random effect of panel model, Hausman test has been estimated. Since the hausman test result shows a p-value of less than 0.05 , the fixed effect model were selected.

Table: 1 fixed effect model regression result

. xtreg NI Depositratio Adv COMM BRA, fe robust

Fixed-effects (within) regression

Group variable: Bank

Number of obs $=101$

R-sq:

within $=0.8135$

between $=0.8927$

overall $=0.8474$

Number of groups $=16$

Obs per group:

$\min =\quad 3$

$\mathrm{F}(4,15)$

$\operatorname{avg}=6.3$

$\operatorname{corr}\left(\mathrm{u} \_\mathrm{i}, \mathrm{Xb}\right)=0.6098$

(Std. Err, adjusted for 16 clusters in Bank)

\begin{tabular}{|c|c|c|c|c|c|c|}
\hline $\mathrm{NI}$ & Coef. & $\begin{array}{l}\text { Robust } \\
\text { Std. Err. }\end{array}$ & $\mathrm{t}$ & $\mathrm{P}>|\mathrm{t}|$ & [95\% Conf. & Interval] \\
\hline Depositratio & $-5.69 e+07$ & $4.00 \mathrm{e}+07$ & -1.42 & 0.175 & $-1.42 e+08$ & $2.83 \mathrm{e}+07$ \\
\hline Adv & 1.972537 & 2.677781 & 0.74 & 0.473 & -3.735017 & 7.680091 \\
\hline COMM & .7226376 & .0613912 & 11.77 & $0.000 * * *$ & .5917853 & .8534898 \\
\hline BRA & 482661.9 & 209002.7 & 2.31 & $0.036 * *$ & 37183.14 & 928140.6 \\
\hline cons & $1.03 \mathrm{e}+08$ & $2.68 \mathrm{e}+07$ & 3.83 & 0.002 & $4.54 \mathrm{e}+07$ & $1.60 \mathrm{e}+08$ \\
\hline
\end{tabular}

\begin{tabular}{|c|c|}
\hline sigma $u$ & 94875309 \\
\hline sigma_e & 44552312 \\
\hline rho & .81932765 \\
\hline
\end{tabular}

$* * *$ significant at $1 \%$

** significant at $5 \%$

The above table presents the regression result of panel data using fixed effect model. The overall $\mathrm{R}^{2}$ value of the result is shown in the table $84.74 \%$. This indicates that $84.7 \%$ of the variation in the dependent variable is explained by explanatory variables.

In the model four explanatory variables were used to explain the dependent variable. These four variables represent 4 Ps' of marketing mix. The first variable is 'Deposit ratio' which is measured as the ratio of total deposit to total asset of the bank. This variable was used as a product of the bank provided to the customers. The result of the model shows that deposit ratio is negatively related with the net income (dependent variable). But it 
is insignificant relationship between the two variables. The reason why the deposit ratio is negatively related with net income is because banks need to pay interest for the deposit amount, which is considered as an expense for the bank. Therefore, as the level of deposit increases the amount of net income would be decreases. Surprisingly this result is inconsistent with Chinweoke et al (2016) result which indicates that there is a significant and positive relationship between the three types of deposit, viz. demand, saving and time deposit and the profitability of the Nigerian banking sector.

The other independent variable is advertising cost which represents the promotion part of 4 Ps'. Indeed, the p-value of the variable is greater than $5 \%$ significance level but it affect the net income of the bank directly. Generally, the result indicates that there is no significant effect of advertising expense on profitability of banks. This is consistent with Riaz et al (2015) where they found that there is no significant effect of advertising expense on return on equity for Public Sector Banks. But it is inconsistent with them regarding with Private Sector Banks since they found that the significance and positive effect of advertising expense on return on equity.

Commission income is considered as another independent variable and represents the price part of marketing mix. The result of the regression shows that the $p$-value of commission is less than 5\% significance level. Therefore, all other things remain constant as the level of commission income increases by birr 1 the level of net income would rises by birr 0.723 . The remaining 0.227 birr might be used as expenditure for covering costs arising from rendering services so as to earn commission income. This indicates that when banks generate commission income, they earn $72.3 \%$ of the total commission income as their net income. It implied that they are very expensive for rendering services to their customers.

The number of branches opened by banks also considered as the fourth independent variable for this study. It represents as the placement of marketing mix. The p-value of this variable is less than $5 \%$ significance level. Thus the numbers of branches opened by banks positively affect the net income of banks. Therefore, all other things are remain constant as the number of branches opened by banks increases by 1 unit, the net income would be increase by birr 482,661.9. This indicates that when commercial banks opened new additional branches their net income level would be increases. This is because they can address more new customer and render more additional services thereby generate more income.

\section{Conclusion}

The study was conducted to examine the relationship between the marketing mix of private commercial banks and their profitability for the period of 2011/12 to 2016/17. Both descriptive and inferential analyses were used to analyze the secondary data. The descriptive analysis indicates that advertising expense is slightly increases from year to year. Similarly, the average income earned from the commission and service charge by banks is increased surprisingly from year to year. In contrary, the average net income of the banks in the study period is declining. Perhaps, this is because banks incurred enormous costs for technological advancement, branch expansion and salary increment for their staff. In light with this, the researcher tried to rank among banks in terms of the birr amount budgeted for advertisement. Consequently, the finding shows that Dashen bank is the first ranked bank which spend huge amount of money for advertisement, followed by Wegagen bank. Regarding with their budget amount for advertisement Debub Global bank is the least one followed by Addis International bank. Concerning with profitability, Dashen bank is scored the highest ROE followed by Awash bank and Zemen bank.

In addition to the descriptive analysis, the researcher tried to examine the relationship between marketing mix and profitability of the bank. Four variables were selected as the dependent variables and used as the representation of four market mix. These variables are deposit to total asset ratio, advertising expense, commission income and number of branches opened by banks which represents product, promotion, price and placement of the market mix respectively. Among the variables, commission income and number of branches opened by banks have positive and significant effect on the profitability of the banks. The other two variables, viz. deposit ratio and advertising expense, do not have significant effect on the profitability of the bank.

\section{Recommendation}

Although interest income is the foremost source of income for banks, now days since the nature of bankcustomer relationship is dynamic, it is advisable for banks to focus on products which contribute a lot for generating non-interest income along with the traditional products. Thus, banks should give attention to issues letter of credit, exchanging currency, agency services, investment and other activities so as to enhance their noninterest income. Branch expansion is still very important part of banks' marketing strategy, since it can be method to increase number of customer. Particularly, a country like Ethiopia where internet accessibility is very low and where most of peoples are difficulty to use E-Banking technology, focusing on branch expansion is indisputable approach. Indeed, there are still significant peoples who desire to approach their bank with the support of E-Banking. Therefore, since online banking is simply faster, easier and more convenient for clients, banks should develop innovative products so as to increase their accessibility. 


\section{References}

Al-Nimer, M. (2015). Factors Affecting Mandatory Audit Rotation Evidence from Jordan. International Journal of Economics and Finance, 7(6).

Ambler, T., Kokkinaki, F., \& Puntoni, S. (2004). Assessing marketing performance: Reasons for metrics selection. Journal of Marketing Management, (20), 475-498.

Anderson, E., Fornell, C., \& Mazvancheryl, S. (2004). Customer satisfaction and shareholder value. Journal of Marketing, (68), 172-185.

Bharadwaj, S., Clark, T., \& Kulviwat, S. (2005). Marketing, market growth, and endogenous growth theory: An Inquiry into the causes of market growth. Journal of the Academy of Marketing Science, 33(3), 347-359.

Charnes, A., W.W. Cooper, and E. Rhodes (1978). "Measuring the Efficiency of Decision Making Units." European Journal of Operational Research, Volume 3: 429-444

Collis, D.J. (1991). "A Resourced-Based Analysis of Global Competition: The Case of the Bearings Industries", Strategic Management Journal, Vol 12, Summer: 49-68

Cook, W., \& Talluri, V. (2004). How the Pursuit of ROMI is changing marketing management. Journal of Advertising Research, 44(3), 244-254.

Douglas, S.P., and C.S. Craig (1989). "Evolution of Global Market Strategy: Scale, Scope and Synergy". Columbia Journal of World Business, Vol 24, No 3: 47-59

Grant,R.M.(1991).“The Resource-Based Theory of Competitive Advantage;Implications for Strategy Formulation”.California Management Review,Volume33, No3;114-135.

Gyorgy Szapary (2001). "Banking Sector Reforms in Hungry: Lessons Learned, Current Trends and Prospects"' Croatian National Bank, June 28-30.

Hardesty, S. D., \& Leff, P. (2010). Determining marketing costs and returns in alternative marketing channels. Renewable Agriculture and Food Systems, 25(1).

Heggestad A. (1977). "Market Structure, Risk and Profitability in Commercial Banking," The Journal of Finance $32,1207-1216$

Kamakura, W.A.; V. Mittal, F. De Rosa, and Mazzon, J.A. (2002). "Assessing the Service-Profit Chain", Marketing Science, Volume 21, No 3; 294-31.

Keltner, B. (1995).Relationship Banking and competitive advantage; Evidence from the US and Germany. California Management Review, Vol 37, No 4(summer), pp.45-72

Kotler, P., Keller, K.L. (2006). Marketing Management, Delhi Prentice Hall of India Private Limited. McDonald, M. (2006). Do your marketing strategies create or destroy shareholder value? Database Marketing and Customer Strategy Management, 13(2), 102-107.

Krasnikov, A., \& Jayachandran, S. (2008). The relative impact of marketing, research and development, and operations capabilities on firm performance. Journal of Marketing, 72(4).

Kumar, M., \& Basu, P. (2008). Effectiveness of marketing expenditures: A brand level case study. Journal of Targeting. Measurement and Analysis for Marketing, 16(3), 181-188.

Marcus O. , Ruth A., Chima K. ,and Abba B. (2017). Impact of New Products Development on the Profitability of Nigerian Deposit Money Banks. International Journal of Economics, Finance and Management Sciences, vol. 5(4).

Mahajan, J. (1999)“A Data Envelopment Analytic Model for Assessing the Relative Efficiency of theSelling Function”. European Journal of Operational Research. Vol. 53: 189-205.

Morgan, N. A., Vorhies, D. W., \& Mason, C. (2009). Market orientation, marketing capabilities, and firm performance. Strategic Management Journal, 30(8), 909-920.

Pualinus P. Ekerete (2005). Marketing of Financial Services; A Case Study of Selected Merchant Banks In Nigeria. Vol. 43

Oneill, J. W., Hanson, B., \& Mattila, A. S. (2008). The relationship of sales and marketing expenses to hotel performance in the united states. Cornell Hospitality Quarterly, 49(4), 355-363

Rodriguez, R. A., \& Berrio, S. P. (2011). The impact of market orientation on the financial performance of MSMES (micro, small and medium enterprises) in Bogota. Papers Administration Valley University, 27(6), 131-140.

Rust, R.T., T. Ambler, G.S. Carpenter, Kumar, V and. Srivastava, R.K (2004). "Measuring Marketing Productivity: Current Knowledge and Future Directions" Journal of Marketing, Volume 68, October: 76-89.

Sheth, J.N., Sisodia, R.S and A. Sharma (2002). "The Antecedents and Consequences of Customer-Centric Marketing" Journal of the Academy of Marketing Science, Volume 28, № 1: 55-66.

Teece, D., Pisano, G and Shuen, A. (1997). "Dynamic capabilities and strategic management." Strategic Management Journal, Volume 18, $\mathrm{N}^{\mathrm{o}}$ 7: 509-533

Van Waterschoot, W., and Van den Bulte, C. (1992). "The 4P Classification of the Marketing Mix Revisited." Journal of Marketing, Volume 56, October: 83-93. 